\title{
SURVEY OF RICE DISEASES AND INSECT PESTS IN NORTHERN GHANA
}

\author{
S. K. Nutsugah', F. K. Tsigbey ${ }^{1}$, I. K. Dzomeku ${ }^{2}$ and I. K. Bimpong1 \\ ${ }^{\prime}$ Savanna Agricultural Research Institute, P. O. Box 52, Tamale \\ ${ }^{2}$ University for Development Studies, P. O. Box 1350, Tamale
}

\begin{abstract}
A survey was conducted in some rice-growing areas of northern Ghana during the rainy seasons of August-November, 1996-98 to determine the prevalence of rice pests with emphasis on diseases. Brown spot (Bipolaris oryzae) was identified as an emerging threat to rice production in the low-input cropping systems of the areas. Leaf blast (Pyricularia oryzae), narrow brown leaf spot (Cercospora janseana), leaf scald (Microdochium oryzae), glume discolouration (caused by several pathogenic fungi), false smut (Ustilaginoidea virens), stackburn (Alternaria padwickii) and sheath rot (Sarocladium oryzae) also occurred sometimes together on farmers' fields. Survey results based on enzyme-linked immunosorbent assay (ELISA) test has confirmed the presence of rice yellow mottle virus in Ghana. Seed sucking bugs, grasshoppers, caterpillars, termites, stem and seed borers, birds and non-parasitic weeds are potential constraints to rice production in the region. The weed species associated with rice production in the region are recorded in the text.
\end{abstract}

Keywords: Diseases, pests, economic importance, rice, survey.

\section{INTRODUCTION}

Rice is an important food and cash crop in Ghana and is currently grown on about 100,000 ha with most of the cultivation under upland/lowland rain-fed conditions (PPMED, 1995). Rice is cultivated under a wide range of climatic conditions, from a dry Savanna climate, with about $900-1,000 \mathrm{~mm}$ of rain, in the northern sector to a humid, tropical climate, with $1400-2,000 \mathrm{~mm}$ of rain, in the south of the country (Dekuku et al., 1991). Only a small area of land $(<2000 \mathrm{ha})$ is irrigated but there is a large potential for developing irrigated rice in the inland valleys, which are presently largely under-utilised (MOFA and CFD, 1997). Eight irrigated rice development projects are located in different parts of the country. These are at Tono and Vea (Upper East Region), Bontanga (Northern Region), Dawhenya (Greater-Accra Region), Kpong and Akuse (Eastern Region), Afife (Volta Region) and Nobewam (Ashanti Region). In-land valley rice is also grown at Aframso (forest-savanna transition zone) and Besease (deciduous rain forest ecology) in Ashanti Region.

Rice production has increased considerably in the past few years, but the current production barely exceeds 221,300 $\mathrm{m} \mathrm{t}$ (PPMED, 1995). Rice consumption isincreasing very rapidly, so its supply is increasingly depending on imports $(170,000 \mathrm{~m} \mathrm{t} / \mathrm{yr}$ on the average, i.e. $67 \%$ of the needs (MOFA and CFD, 1997).

Biotic factors especially diseases, non-parasitic weeds, bird damage and insect pests cause substantial losses annually to the rice crop (Nutsugah, 1997). Although losses have not been accurately assessed, they could be similar to those reported for other similar areas in West Africa where yield losses caused by arthropod pests, diseases and weeds are generally estimated to be about 30\% (WARDA, 1991). However, many rice diseases and insect pests occur sporadically, and can result in total crop loss. The identification and development of varieties with resistance or tolerance to diseases and insect pests would, therefore, be of considerable benefit in stabilizing rice production in Ghana. Since scanty information on the occurrence and severity of rice diseases and insect pests in the country was available, this study was undertaken with the objectives of (i) defining the rice diseases and insect pests situation in rice fields in northern Ghana, (ii) investigating farmers' perception of the importance of rice diseases and insect pests in their farms and (iii) assessing their relative importance in the northern sector of the country.

\section{Materials and Methods}

Experimental rice plots and farmers' fields were surveyed for fungal and viral diseases in the Northern and Upper East Regions of Ghana. The survey was 
timed to coincide with the wet season in AugustOctober of 1996-98 so that the crops could be observed in the fields and for the farmers to have improved knowledge/awareness of the extent and severity of crop pests and diseases. Interviews with farmers were conducted without prior notification. Information collected from farmers included biodata, crop acreage, pests incidence and their control measures. The survey was conducted during the maturity stage of the crop (1-2 weeks before harvest). Plants in each field were observed at nine different locations or sites at random; the four corners, midway along each edge and at the - centre on at least 5 farms at cach location. The visual scores for severity or incidence of diseases were recorded using the IRRI Standard Evaluation System for Rice on a scale of 0-9 (IRRI, 1996). Leaf blast and scald samples were collected from each site, preserved and mailed to CABI Bioscience, Horticulture Research International and Natural Resources Institute, UK, for characterization of the pathogenic fungal populations, and, leaf samples showing rice yellow mottle virus symptoms were sent to West Africa Rice Development Association (WARDA), Bouaké, Côte d'Ivoire, for enzyme-linked immunosorbent assay (ELISA) test to confirm the presence or absence of the virus in the leaf samples.

Non-parasitic weed species and their percent occurrence associated in a hydromorphic rice experimental field at Nyankpala were closely monitored during the 1996-98 rainy seasons. The visual score of percent occurrence of weeds was recorded 30 and 77 days after seeding (to coincide with sensitive growth stages of tillering and heading, respectively) on a scale of $1-3$, where 1 is low occurrence indicating $10-30 \%$ coverage of the plot area, 2 is moderate occurrence indicating $40-50 \%$ coverage of the plot area and 3 is high occurrence indicating more than $50 \%$ coverage of the plot area.

The African rice gall midge (ARGM), Orseolia oryzivora, damage was assessed between AugustOctober 1996 and 1997 in the hydromorphic/lowland rice ecologies in four villages around Nyankpala, namely Kukpehi, Kpinginga, Kpalsugu and Golinga in Northern Region where rice varieties GR 18 and 19 were mostly grown by the farmers. The survey covered the vegetative and near booting stages ( 3 weeks after panicle initiation) of the crop. In each farm the total number of tillers and number of tillers with galls were recorded and the percentage of infested tillers for all the sampled hills in the fields was calculated. Twenty hills per field were sampled at random in each village.

\section{Results}

Occurrence of the dominant rice discases arising from natural infection in the fields varied considerably among the different rice-growing areas in the Northern and Upper East Regions (Table 1).

Brown spot: Brown spot (Bipolaris oryzae =Cochliobolus miyabeanus = Drechslera oryzae) was the most predominant and most widely distributed foliar disease of rice in northern Ghana. The disease was observed at seventeen locations surveyed with severity ratings of 0-3 (low), 4-6 (moderate) and 7-9 (high) at eight, five and four locations, respectively (Tables 1 and 5).

Leaf blast: Leaf blasi (Pyricularia oryzae =: Magnaporthe grisea) was second in prevalence to brown spot and was present at sixteen locations surveyed. The leaf blast severity ratings varied from 0-9 with 0-3 at nine locations, 4-6 at five locations and 7-9 at two locations (Tables 1 and 5). Molecular and pathological tools were employed to determine the diversity and distribution of Ghanaian blast lineages and pathotypes prevalent in the surveyed areas.

Narrow brown leaf spot: Narrow brown leaf spot (Cercospora janseana) was the third most common disease and observed at nine locations with severity ratings of 0-3 at two locations, 4-6 at six locations and 7-9 at one location (Table 1).

Leaf scald: Leaf scald (Microdochium oryzae =Monographella albescens = Rhynchosporium oryzae) was the fourth in relative abundance and was present at twelve locations with varied severitics of 0 3 (seven locations), 4-6 (four locations) and 7-9 (one location) (Tables 1 and 5). Molecular and pathological tools were also employed to characterise Ghanaian leaf scald isolates.

Glume discolouration: Glume discolouration or dirty panicle disease complex also occurred widely in thirteen locations and on the average, low (0-3) to moderate (4-6) severity infection levels were recorded (Table 1). 
Table 1. Occurrence of dominant rice diseases in northern Ghana during 1996-98 rainy seasons

\begin{tabular}{|c|c|c|c|c|c|c|c|c|}
\hline \multirow{2}{*}{ Location } & \multicolumn{8}{|c|}{ Score $(0-9)^{3}$} \\
\hline & $\begin{array}{l}\text { Brown } \\
\text { spot }\end{array}$ & $\begin{array}{l}\text { Lcaf } \\
\text { blast }\end{array}$ & $\begin{array}{l}\text { Narrow } \\
\text { brown } \\
\text { lcaf spot }\end{array}$ & $\begin{array}{l}\text { Lcaf } \\
\text { scald }\end{array}$ & $\begin{array}{c}\text { Glume } \\
\text { discolouration }\end{array}$ & $\begin{array}{l}\text { False } \\
\text { smut }\end{array}$ & $\begin{array}{l}\text { Sheat } \\
\text { rot }\end{array}$ & $\begin{array}{l}\text { Rice yellow } \\
\text { mottle virus }\end{array}$ \\
\hline \multicolumn{9}{|c|}{ Northern Region } \\
\hline Bontanga & $7-9$ & $4-6$ & $2^{2}$ & $0-3$ & $4-6$ & - & - & - \\
\hline Golinga & $0-3$ & $0-3$ & - & $4-6$ & - & - & - & - \\
\hline Kadia & $0-3$ & $0-3$ & - & - & - & - & - & - \\
\hline Kpalsugu & $0-3$ & $0-3$ & - & $0-3$ & - & - & - & - \\
\hline Kpinginga & 46 & $0-3$ & - & $0-3$ & - & - & - & - \\
\hline Kukpehi & $0-3$ & $0-3$ & - & $4-6$ & - & - & - & - \\
\hline Loagri & $7-9$ & $0-3$ & $4-6$ & - & $0-3$ & - & - & - \\
\hline Nabogu & $0-3$ & $0-3$ & $0-3$ & - & $0-3$ & - & - & - \\
\hline Nasia & $4-6$ & $4-6$ & $4-6$ & - & $0-3$ & - & - & - \\
\hline Nyankpala $^{3}$ & $7-9$ & $7-9$ & $4-6$ & $7-9$ & $4-6$ & $0-3$ & $0-3$ & $0-3$ \\
\hline Salaga & $0-3$ & - & $4-6$ & - & $0-3$ & $0-3$ & - & - \\
\hline Savclugu & - & - & - & $0-3$ & $0-3$ & - & - & - \\
\hline Taha & $0-3$ & $0-3$ & - & - & $0-3$ & - & - & - \\
\hline Yepeligu & $0-3$ & $0-3$ & $0-3$ & $0-3$ & $0-3$ & - & $0-3$ & - \\
\hline \multicolumn{9}{|c|}{ Upper East Region } \\
\hline Bolgatanga & $7-9$ & $7-9$ & $7-9$ & $0-3$ & $0-3$ & - & - & - \\
\hline Fumbisi & - & - & - & - & - & - & - & - \\
\hline Manga $^{3}$ & 46 & $4-6$ & 46 & $0-3$ & $0-3$ & - & - & - \\
\hline Navrongo & 46 & $4-6$ & $4-6$ & $4-6$ & $4-6$ & - & - & - \\
\hline Tono & $4-6$ & $4-6$ & - & $4-6$ & $0-3$ & - & - & - \\
\hline
\end{tabular}

'Visual scores of disease incidence and severity were recorded using the IRRI standard evaluation system where $0-3=$ severity or incidence of $0-5 \%$ of affected leaf area or infected florets or florets with discoloured glumes), 4-6 = severity or incidence of $6-25 \%$ of affected leaf area or infected florets or florets with discoloured glumes) and 7-9 = severity or incidence of $>25 \%$ of affected leaf area or infected florets or florets with discoloured glumes).

${ }^{2}$ Disease not recorded,

${ }^{3}$ Experimental rice sites. 
Table 2: Reactions of some varieties to rice yellow mottle virus screened at Nyankpala

\begin{tabular}{|l|c|c|}
\hline \multicolumn{1}{|c|}{ Entry } & Score (1-9) & ELISA test \\
\hline Tox 85C-C5-106-3-3 & 3 & Positive \\
\hline Bouake 189 & 3 & Positive \\
\hline CT 9506-42-1-1 & 1 & Negative \\
\hline Tox3972-10-1-2-1-1-3-2 & 1 & Negative \\
\hline CT 8837-1-7-1P & 1 & Negative \\
\hline BD2 & 1 & Negative \\
\hline Tox 4009-8-13-2-2-1 & 3 & Positive \\
\hline CENTAA1 & 3 & Positive \\
\hline WITA 8 & 1 & Negative \\
\hline WITA1 & 1 & Negative \\
\hline WITA 10 & 1 & Negative \\
\hline WITA4 & 3 & Positive \\
\hline WITA3 & 3 & Positive \\
\hline WITA9 & 1 & Negative \\
\hline WITA7 & 1 & Negative \\
\hline
\end{tabular}

'Visual scores of RYMV incidence and severity were recorded using the IRRI Standard Evaluation System, 1996.

Table 3: Percentage of farmers reporting insect pests and other potential constraints on rice in northern Ghana

\begin{tabular}{|l|c|}
\hline \multicolumn{1}{|c|}{ Pest/Constraint } & \% Farmers reporting ${ }^{1}$ \\
\hline Suckling bugs & 57 \\
\hline Grasshopper & 29 \\
\hline Caterpillars & 29 \\
\hline Termites & 29 \\
\hline Stem borers & 14 \\
\hline Birds & 57 \\
\hline on-parasitic weeds & 280 \\
\hline
\end{tabular}

'Percent occurrence of constraints from six sample farms ( 30 farmers) in Northern Region. 
Table 4: Weed species associated with on-station hydromorphic rice,

Nyakpala 1996-98

\begin{tabular}{l|c}
\hline Weed species & $\begin{array}{c}\text { Weed occurrence } \\
\text { score }(\mathbf{1}-\mathbf{3})^{\mathbf{1}}\end{array}$ \\
\hline Grasses & \\
Eragrostis atrovirense & 2 \\
Echinochloa pyramidalis & 2 \\
Setaria pallide-fusca & 3 \\
Rottboellia cochinchinensis & 3 \\
Brachiaria deflexa & 1 \\
Oryza barthii & 2 \\
Paspalum orbiculare & 1 \\
Eleusine indica & 1 \\
& \\
Broad leaves & \\
Ageratum conyzoides & 3 \\
Hyptis spicigera & 3 \\
Eclipta prostrata & 1 \\
Hibiscus spp. & 1 \\
Phyllantus amarus & 1 \\
Ipomoea acquatica & 1 \\
Desmodium spp. & 1 \\
Ludwigia spp. & 1 \\
Scoparia dulcis & 1 \\
Sedges & \\
Commelina africana & \\
Cyperus difformis & 1 \\
Cyperus iria & 3 \\
Fimbrystylis littoralis & 3 \\
Pycreus lanceolatus & 3 \\
\hline
\end{tabular}

Weed occurrence sco

'Mean weed score recorded 77 days after seeding on a a scale of 1-3, where 1 is low occurrence indicating $10-30 \%$ coverage of plot area, 2 is moderate occurrence indicating $40-50 \%$ coverage of plot area and 3 is high occurrence indicating more than $50 \%$ coverage of plot area. 
Table 5: Call midge damage and severity of foliar discases in four villages in the vicinity of Nyankpala

\begin{tabular}{|l|c|c|c|c|c|c|}
\hline & \multirow{2}{*}{$\begin{array}{c}\text { Gall midge } \\
\text { infestation } \\
(\%)\end{array}$} & \multirow{2}{*}{$\begin{array}{c}\text { Gall midge } \\
\text { reaction }\end{array}$} & \multicolumn{3}{|c|}{ Disease scorc (0-9) } & \\
\cline { 4 - 7 } & & Leaf blast & Brown spot & Leaf scald & \\
\hline Kukpehi & 28 & HS & 2 & 1 & 6 & -4 \\
Kpinginga & 24 & S & 1 & 4 & 3 & - \\
Kpalsugu & 26 & HS & 2 & 1 & 3 & - \\
Golinga & 34 & HS & 2 & 3 & 5 & - \\
Mcan $^{5}$ & 28 & & 1.8 & 2.3 & 4.3 & - \\
& & & & & & \\
\hline
\end{tabular}

'Infested tillers/total tillers (20 hills),

${ }^{2}$ Reaction of tillers with silver shoot (\%) were recorded using IITA standard evaluation system for gall midge resistance where HS is highly susceptible ( $>25 \%)$ and $\mathrm{S}$ is susceptible (11-25\%),

${ }^{3}$ Visual scores of incidence and severity of secdling blast, brown spot and leaf scald were recorded using the IRRI standard evaluation system,

${ }^{4}$ Disease not recorded and

${ }^{5}$ Mean of 20 hills per field sampled.

False smut, stackburn and sheath rot: The least occurring diseases were false smut (Ustilaginoidea virens), stackburn (Alternaria padwickii) and sheath rot (Sarocladium oryzae). Falsc smut and shcath rot discases had severity ratings of $0-3$ at two locations (Table 1). Stackburn, on the other hand, has not been included in the table because of its infrequent and sporadic incidence and presently does not cause any serious damage to rice production in the region.

Rice yellow mottle virus: Rice yellow mottle virus (RYMV) was the only viral discase observed and was confined to the experimental rice fields at Nyankpala (Table 1). Out of fiftecn leaf samples exhibiting viruslike symptoms that were processed using the enzymelinked immunosorbent assay (ELISA) test, six reacted positively to the antisera developed for RYMV while nine reacted negatively (Table 2). Efforts are being made by the Savanna Agricultural Research Institute, Nyankpala to monitor the seasonal occurrence of the virus in lowland rice ecologics. During the entire study period, RYMV was confined to Nyankpala as a result of intensive rice screcning rescarch activity. Even though the virus is naturally transmitted by several species of beetles and mechanical transmission, the mode of transmission at Nyankpala is not known.

Farmers' perception: The farmers' perception of insect pests and other potential constraints to rice production are shown in Table 3 . More than $80 \%$ of the farmers reported non-parasitic weeds as the most important constraint in rice followed by birds and seed sucking bugs (57\%). At least $29 \%$ of the farmers reported grasshoppers, caterpillars and termites as potential constraints. About $14 \%$ of the farmers recorded stem borers as the least constraint in their crop.

Weed spectrum: The weed species associated with the experimental hydromorphic rice field at Nyankpala are shown in Table 4. Seven weed species had the highest score of 3 . These are Rottboellia cochinchinensis (grass), Ageratum conyzoides, Hyptis spicigera (broad leaves) and Cyperus iria, Fimbrystylis littoralis and Pycreus lanceolatus (sedges). Four weed species had a score of 2 while the remaining twelve weed species had a score of 1 . In addition to non-parasitic weeds that are important constraints to rice production, the parasitic weed, Striga hermonthica was also seen in farmers' fields at Loagri in Northern Region during 1997 rainy season.

African rice gall midge (ARGM): The feeding of the larvae on the leaf sheath create a cavity where the larvac are lodged, and cause the leaf sheath to develop into an onion-like gall called an onion leaf or silver shoot. The damage results in stunting of plant 
and the affected tillers do not produce panicles. The distribution and infestation of gall midge in four villages in Northern Region are summarizcd in Table 5. The highest infestation occurred in Golinga (34\%), followed by Kukpehi (28\%), Kpalsugu (26\%) and Kpinginga (24\%). From the results obtained, it appears that farmers in the four villages grow susceptible varietics, rather the pest thrives in rain-fed lowland ecologies and its abundance is favoured by cloudy or rainy conditions and can attack even improved rice varietics.

\section{Discussion}

The prevalence of foliar discases, namely brown spot, leaf blast, narrow brown leaf spot and/or leaf scald at Loagri, Nyankpala and Bolgatanga may be influenced by the subsistence farming cultivation methods in these areas. The high incidence of these diseases suggests that not only is rice intensively cultivated in these areas for five or more consecutive years but also those farmers grow susceptible varieties. The surveyed ficlds were generally small (0.6-1.2 ha) and surrounded by grasses or sedges. These probably favour longer retention of water droplets from rain or dew that are prerequisite for successful germination of fungal spores and subsequent invasion (Ou, 1985). The relatively high incidence and severity of brown spot and narrow brown leaf spot in northern Ghana can also be attributed to other conditions such as low fertility of the soil. Brown spot, which is associated with nutrient imbalances such as potassium deficiency (Awoderu, 1974; Ou, 1985), is of significance in the northern sector. The diversity and distribution patterns of Ghanaian blast isolates have been grouped into three distinct lineages designated as GH-1, GH-2 and GH-3 (Sreenivasaprasad and Chipili, 1998). Limited molecular variability was observed in leaf scald genome for which pathogenicity testing (Turner, 1998) was initiated. Glumes discolouration was found to influence percentage germination of affected rice varieties adversely (Twumasi, 1995) and also posing serious threat to the quality $n$ seed rice. This is due to the fact that the diseas . is characterised by darkening of glumes of spikelets with brown colour to black including rotten glumes caused by attack ofone or more fungal pathogens (Nutsugah and Twumasi, 2001; SARI, 1996).

The survey result based on the ELISA test from plants showing virus-like symptoms indicated the presence of RYMV in Ghana. However, the incidence of RYMV in the experimental rice fields at Nyankpala was low and sporadic $(<5 \%)$. Brown spot, lcaf blast, narrow brown leaf spot, leaf scald, glume discolouration and RYMV occurred throughout the entire study period while false smut was obscrved in 1997 and sheath rot in 1996. The experimental rice fields (Nyankpala, Salaga and Manga) were located at the same sites for the three-ycar running while the farmers' ficlds were located within the same locality but not necessarily at the same site.

The ARGM survey gave an indication that the tiny mosquito-like insect was prevalent in the four villages sampled during the rainy scasons of 1996 and 1997. Severe infestation as observed at Kukpehi, Kpalsugu and Golinga could result in total crop failure. Cultivation of resistant varictics is therefore recommended for farmers in the four locations where the survey was conducted. This is because the insect pest becomes highly abundant during the rainy scason in the rain-fed wetland environment of the four villages.

The non-parasitic weed species at the Nyankpala hydromorphic experimental site consisted $27 \%$ grasses with C4 photosynthetic pathways (Akobundu, 1987). These species, Brachiaria deflexa, Digitaria horizontalis, Echinochloa pyramidalis, Eleusine indica, Eragrostis atrovirense, Paspalum orbiculare and Rottbocllia cochinchinensis have been documented to have competitive edge over arable rice, most especially in the savanna ccology probably because of their higher water use efficiencies (Akobundu, 1987; Moody, 1994). Cyperus difformis and Ipomoea aquatica have also becn reported to cause economic yicld loss in rice (Akobundu, 1987). In addition, Oryza barthii which can serve as alternative host to rice fungal pathogens is a dangerous weed in rice probably because it mimics both the vegetative and reproductive stages of rice and cannot be controlled with herbicides selective to rice (Akobundu, 1987).

Farmers demonstrated a decp understanding of the rice ecosystem and the constraints that limit production. Resource-limited farmers in general regarded diseases and weeds as the most important constraints. Insect pests such as seed sucking bugs, grasshoppers and termites wcre also mentioned as production constraints. The disease/insect pest awareness was lacking in some farming communities especially where brown spot and glume discolouration were conspicuously widespread. Nevertheless, some farmers attributed discases like brown spot, leaf blast, narrow brown leaf spot and lcaf scald to drought condition, which is common in the northern sector of the country. This assertion is confirmed by several workers who have demonstrated 
that water stress predisposes rice plants to leaf and neck blast and brown spot (Bidaix, 1978; Ou, 1985). Farmers who are aware of the disease/insect pest incidence did not report any type of control, chemical or traditional. Most farmers scared birds off their fields to prevent bird damage.

The general observation revealed lack of knowledge of diseases by some peasant farmers. The small-scale farmers practised no apparent control measure. Brown spot has assumed higher incidence probably due to lack of proper nutrient in the soil and water stress situation (Bidaix, 1978; Ou, 1985) which is common in northern Ghana. In areas where brown spot disease is severe and associated soil abnormalities are not easily corrected, resistant varieties should be introduced or developed. Variations in disease incidence and severity were apparent in the different rice-growing areas of northern Ghana. Mixed infection of brown spot, narrow brown leaf spot and leaf blast was a common occurrence in most of the fields surveyed.

\section{Conclusions}

A number of diseases of rice have been recorded in northern Ghana. Brown spot and leaf blast are dominant and widespread in distribution, and are more devastating than the other diseases recorded, notably narrow brown leaf spot, leaf scald, glume discolouration, false smut, stackburn and sheath rot. The occurrence of rice yellow mottle virus in northern Ghana was confirmed (Anno-Nyako et al., 1996) by the survey. Many of the pests associated with rice were of minor importance and occurred sporadically. However, African rice gall midge infestations of 24$34 \%$ in the areas surveyed is disturbing because there is the likelihood that the pest can cause serious yield losses. Non-parasitic weeds, pod sucking bugs and bird damage is potential constraints to rice production in the two regions.

Farmers' perceptions of the importance of rice diseases and insect pests are related to a number of factors. These include the symptoms of the diseases and insect pests, the importance of the crop in the farming system and lack of information available to the farmers including extension messages on control measures. A socioeconomic assessment of these factors will assist in understanding farmers' perceptions of diseases and insect pests and why they adopt certain management strategies.

\section{Acknowledgements}

The research was supported in part by grants from the National Agricultural Research Project 12-010 to the first author.

\section{References}

1. Akobundu, I. O. (1987). Weed Science in the Tropics: Principles and Practices. John Wiley and Sons, New York, 522 pp.

2. Anno-Nyako, F. O., Owusu-Akyaw, M., Twumasi, J. K., (1996). The incidence of rice yellow mottle virus in some major rice producing areas of Ghana. Proc. of the $5^{\text {th }}$ Annual WARDA Integrated Pest Management -Task Force mecting, March 20-22, 1996, Bouaké, Côte d'Ivoire.

3. Awoderu, V.A., (1974). Rice diseases in Nigeria. PANS 20, 416-424,

4. Bidaix, J. M. (1978). Screening for horizontal resistance to rice blast (Pyricularia oryzae) in Africa. In: Buddenhagen, I. W., Persley, G. J. Eds. Rice in Africa. Academic Press, London, pp. 159174.

5. Dekuku, R. C., Kasei, C. N., Rebuffel, P., Dogbe, W., Nyamekye, A. L. (1991). Attempts at characterization of rice growing environments in the northern savanna of Ghana. In: Proc. Workshop on Collaboration in the characterization of continuum environments in West Africa, June 4-5, Bouaké, Côte d'Ivoire.

6. International Rice Research Institute (IRRI) (1996).Standard Evaluation System for Rice. The International Network for Genetic Evaluation of Rice, $4^{\text {th }}$ edition, July 1996 , IRRI, Manila, Philippines, $52 \mathrm{p}$.

7. Ministry of Food and Agriculture (MOFA) and Caisse Francaise de Developpment (CFD) Draft Report, (1997). Feasibility study of rice development project in Northern Region in Ghana, $114 \mathrm{p}$.

8. Moody, K. (1994). Weed management in rice. In: Weed Management for developing countries. FAO Plant Production and Protection Paper No. 120, Rome, pp. 273-128. 
9. Nutsugah, S. K. (1997). Survey of rice diseases/ pests in northern Ghana. Proc. of the $6^{\text {th }}$ Annual WARDA Integrated Pest Management -Task Force meeting, March 2-5, 1997, Bouaké, Côte d'Ivoire.

10. Nutsugah, S. K., Twumasi, S. K. (2001). Fungal Discases of Rice in Ghana: Knowledge and Research Needs. In: Major Fungal Diseases of Rice Recent Advances (S. Sreenivasaprasad and R. Johnson, eds.) Kluwer Academic Publishers, The Netherlands, pp. 321-329.

11. Ou, S. H. (1985). Rice Diseases. Commonwealth Mycological Institute, Kew, England. $2^{\text {nd }}$ Edition, $380 \mathrm{pp}$.

12. Policy Planning, Monitoring and Evaluation Department [PPMED](1995). Statistics Division, Ministry of Food and Agriculture, Ghana. 30 p.
13. Savanna Agricultural Research Institute [SARI] (1996): Annual Report, 276 p.

14. Sreenivasaprasad. S., Chipili, J. (1998). Molecular charaterisation of the blast pathogen Magnaporthe grisea from some West African rice screening sites. Proc. of the ICPP 98 (Edinburgh, UK), p. 122.

15. Turner, H. C. (1998). Molecular variability of rice leaf scald pathogen, Monographella albescens. Proc. of the ICPP 98 (Edinburgh, UK), p. 68.

16. Twumasi, J. K. (1995). The grain discolouration syndrome of rice in Ghana. Proc. of the $4^{\text {th }}$ Annual WARDA IPM Task Force meeting, March 1517, Bouaké, Côte d'Ivoire.

17. West Africa Rice Development Association [WARDA] (1991). Annual Report, 107 p. 